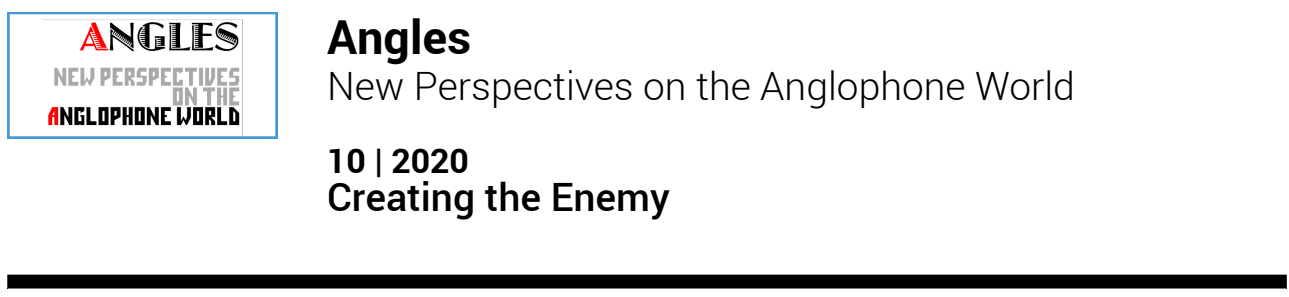

\title{
Video introduction to issue 10
}

\section{Cécile Dudouyt and Jacob Maillet}

\section{(2) OpenEdition}

\section{Journals}

Electronic version

URL: http://journals.openedition.org/angles/283

DOI: 10.4000/angles.283

ISSN: 2274-2042

\section{Publisher}

Société des Anglicistes de l'Enseignement Supérieur

\section{Electronic reference}

Cécile Dudouyt and Jacob Maillet, «Video introduction to issue 10 », Angles [Online], 10 | 2020, Online since 01 April 2020, connection on 24 September 2020. URL : http://journals.openedition.org/angles/ 283 ; DOI : https://doi.org/10.4000/angles.283

This text was automatically generated on 24 September 2020.

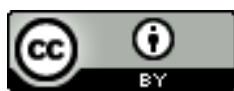

Angles est mise à disposition selon les termes de la Licence Creative Commons Attribution 4.0 International. 


\title{
Video introduction to issue 10
}

\author{
Cécile Dudouyt and Jacob Maillet
}

This media file cannot be displayed. Please refer to the online document http:// journals.openedition.org/angles/283

\section{Transcript:}

1 The concept of the enemy image was developed at the end of the Cold War by psychologists working on international relations such as Ralph K. White and Jerome D. Frank. What's interesting about this concept is that it links discourse analysis and image analysis to psychological mechanisms that are common to all humans and human societies. Even though the concept was inherited from the Cold War it remains relevant today given the fact that we are constantly bombarded with enemy images.

2 This collection of articles does not purport to be an exhaustive catalogue of all enemy images. Rather, it provides insights into the articulation between 1) the fundamental anthropological process of othering, 2) its product: enemy images as weaponised products of othering, 3) and their strategic political use in the politics of fear.

Enemy images come out of an in-group/out-group dynamic in human societies. Within this framework, stereotypes develop when there is a strong rejection of a specific other by a given community. In time, such stereotypes coalesce into "enemy images," that is, caricatures, images to be hated. This is where the image often becomes distinct from the enemy itself, because its characteristics become far removed from reality.

4 Because the mechanisms at work, psychological and political, are always the same, enemy images are often similar. The enemy is barbaric, animalistic, primitive, aggressive... It must be legitimate to hate him, kill him, or even, in the nuclear era, annihilate him.

5 From a literary perspective, since part of the thrill of fiction is to live other lives vicariously, things are usually less clear-cut. There can be a glamour, a dark attraction to the enemy. 

We also have the civilization angle in Martin Berny's article about the stereotypes of Indians in Hollywood movies or even in Maxime Dafaure's article about the alt-right's memes today. And we have the nationalistic with the French enemy in Hervé Campangne's article comparing 1793 and 2003. Kristine Chick, in her analysis of Ken Loach's Ae Fond Kiss shows how the film holds the mirror to the implicit Irish "us": you think of the Muslim "them" as religious fanatics, but what about "us" Catholics? AnneLise Marin-Lamellet, in "Mad, Bad and Dangerous hoodies in Contemporary British Horror films," explores the pragmatics of the enemy image. Behind the spectacular depiction of angry young men, there is the hidden pointing hand, a political agenda actively stereotyping a whole social class, leading to her conclusion that "the worst enemy of the nation may be the excommunicators themselves". Olivier Maheo in "The Enemy within" discusses the role played by photographs in the long Civil Rights Movement and shows that, implicit in every enemy image there is a narrative: vilified bad guys (them) and implicit good guys (us). That article explores two ways of fighting enemy images: through proposing another enemy (racist white trash / violent black nationalist), but also through images of solidarity and kindness to children. Thomas Williams in "Meeting the Enemy", about British-German Encounters in the Occupied Rhineland after World War I explores another factor of the dissolution of enemy images, as real-life encounters with the enemy forces the narrative to evolve.

11 The modern era has accelerated the political time as technological developments have made communication faster and easier. Politicians have been quick to seize the opportunity to consolidate their power and legitimacy by demonising enemies, both within and without their own societies.

We want to believe that the worst excesses are already in our past, but as Jérôme VialaGaudefroy's article on US presidential discourse shows, even democracies are not immune to the politics of fear. The media's taste for sensationalism further amplifies the phenomenon, creating the impression that the world is a violent and dangerous place.

13 Images of enemies have multiplied. With the internet, anyone can now spread fear and hatred to advance their own cause. Movements based on hatred themselves generate further hatred and distrust, fuelling political polarisation and activism. Eventually, "both sides" of any argument become virtually indistiguishable and rational discourse and compromise prove almost impossible. 
14 In the end, the only way to break the cycle is to expose the enemy images for what they are: fictions born from prejudice and fear.

\section{ABSTRACTS}

This video introduces the thematic contributions on 'Creating the Enemy'.

La vidéo présente les contributions thématiques sur « L'image ennemie ».

\section{INDEX}

Mots-clés: ennemi, image ennemie, littérature, histoire, politique, media Keywords: enemy, enemy image, history, literature, politics, media

\section{AUTHORS}

\section{CÉCILE DUDOUYT}

Guest editor of Issue 10. Cécile Dudouyt is assistant Professor at Paris 13 where she teaches French-English Translation and Translation Studies. Her research explores the reception of Sophocles in English and in French from the Renaissance to the Enlightenment. Contact: cecile.dudouyt[at]univ-paris13.fr

\section{JACOB MAILLET}

Guest editor of Issue 10. Jacob Maillet teaches legal English and Constitutional Law at Paris University. He has worked on the influence of the enemy image on both American domestic and foreign politics, from the Cold War to the present day. Contact: jacob.maillet[at]parisdescartes.fr 